\title{
PENGARUH MODEL PROJECT BASED LEARNING TERHADAP MOTIVASI BELAJAR SISWA
}

\author{
Widya Ayu Pangesti ${ }^{1}$, Achmad Fanani ${ }^{2}$, Danang Prastyo ${ }^{3}$ \\ ${ }^{1}$ Prodi Pendidikan Guru Sekolah Dasar, Universitas PGRI Adi Buana Surabaya, Surabaya, Indonesia \\ ayupangestiwidya@gmail.com, fanani@unipasby.ac.id, danang@unipasby.ac.id
}

\begin{abstract}
Informasi Artikel
Abstract

Keywords:

Project based learning,

Motivasi,

Sekolah dasar.

Diterima: 24-09-2020

Disetujui: 07-10-2020

Dipubikasikan: 25-11-2020

Penelitian ini bertujuan untuk mengetahui ada tidaknya pengaruh model pembelajaran berbasis proyek terhadap motivasi belajar siswa kelas III SDN Keboananom Sidoarjo, dengan menggunakan teknik cluster sampling yaitu kelas III-B sebagai kelas kontrol dan III-C sebagai kelas kontrol. kelas eksperimen. Teknik pengumpulan data menggunakan angket siswa. Teknik analisis data menggunakan statistik inferensial non parametrik dengan menggunakan SPSS. Hasil homogenitas penelitian diperoleh nilai sig $0,297>0,05$ yang artinya data homogen, uji normalitas pada kelas kontrol sig $0,04<0,05$ dan normalitas kelas eksperimen sig 0,02<0,05, maka disimpulkan data tidak berdistribusi normal. Hasil uji hipotesis diperoleh Sig. (2-tailed) $0,000<0,05$ sehingga H_O ditolak, sehingga dapat disimpulkan bahwa terdapat pengaruh model pembelajaran Project Based Learning terhadap motivasi belajar siswa kelas III SDN Keboan Anom Sidoarjo.
\end{abstract}

\section{PENDAHULUAN}

Pembelajaran merupakan suatu usaha dari pendidik untuk membuat peserta didik belajar dengan baik, yaitu dengan adanya perubahan tingkah laku pada diri peserta didik yang belajar. Dimana perubahan tingkah laku tersebut akan didapatkan dalam waktu tertentu dan karena adanya usaha dari diri peserta didik. Dalam proses pembelajaran, keberhasilan peserta didik dalam belajar dipengaruhi oleh model pembelajaran yang inovatif dan motivasi belajar dalam diri peserta didik (Setiawan et al., 2020). Permasalahan yang sering dijumpai saat ini adalah kurangnya motivasi belajar peserta didik dalam mengikuti pembelajaran berlangsung. Hal ini disebabkan karena model pembelajaran yang digunakan oleh pendidik kurang inovatif sehingga peserta didik kurang bersemangat (Setiawan \& Iasha, 2020).

Mc.Donald (dalam Sadirman, 2012) mengemukakan bahwa motivasi merupakan suatu perubahan energi dalam diri sesorang yang ditandai dengan munculnya "feeling" dan didahului dengan tanggapan terhadap adanya tujuan. Peserta didik yang termotivasi belajar akan memberikan respon dan selalu memperhatikan terhadap apa yang diinstruksikan oleh pendidik serta menunjukkan antusiasme terhadap aktivitas belajar. Begitu sebaliknya, peserta didik yang tidak memiliki motivasi belajar biasanya tidak 
memperhatian selama pembelajaran dan kurang memilki komitmen untuk mencapai tujuan belajar. Dapat dikatakan bahwa motivasi belajar merupakan suatu kekuatan yang dapat mendorong peserta didik untuk belajar sehingga akan tercapai prestasi dan hasil belajar yang baik.

Salah satu faktor yang sangat penting agar motivasi belajar muncul dalam diri peserta didik adalah pendidik, dimana pendidik harus menciptakan dan mengembangkan pembelajaran agar peserta didik termotivasi untuk bergerak, belajar dalam kelompok, memberikan kesempatan untuk terlibat langsung dalam pembelajaran, serta memberikan pembelajaran nyata sehingga akan lebih bermakna. Seorang pendidik seharusnya mampu memilih dan menggunakan model pembelajaran yang menyenangkan untuk meningkatkan motivasi belajar peserta didik sesuai dengan pokok bahasan yang akan disampaikan. Project Based Learning merupakan model pembelajaran yang cocok dengan kurikulum 2013 karena berbasis proyek yang bisa menambah pengetahuan, sikap dan keterampilan peserta didik.

Model pembelajaran Project Based Learning merupakan model yang menggunakan proyek sebagai tujuan pembelajaran. Hal utama dalam model pembelajaran ini adalah aktivitas peserta didik yaitu pengumpulan informasi dan pemanfaatan untuk menghasilkan sesuatu yang bermanfaat bagi kehidupan peserta didik sendiri atau bagi orang lain, namun tetap berkaitan dengan kompetensi dasar dalam kurikulum. Hal tersebut dijelaskan oleh Kosasih (dalam Kodir, 2018).

Paul Suparno (dalam Trianto, 2015) juga mengatakan bahwa PjBL merupakan pembelajaran dimana peserta didik dalam kelompok diminta untuk membuat dan melakukan suatu proyek secara bersama sama, kemudian mempresentasikan hasil dari proyek yang telah dibuat. Dapat disimpulkan bahwa model Project Based Learning menggunakan masalah sebagai langkah awal dalam mengintegrasikan pengetahuan baru berdasarkan pengalaman nyata sehingga dapat memberikan kesempatan pada peserta didik untuk mengembangkan seluruh potensi yang dimilikinya dan mampu mengembangkan kreativitasnya untuk menghasilkan sebuah produk nyata berupa barang yang bermakna dan bermanfaat.

Muliawati (2010) mengatakan bahwa terdapat beberapa kelebihan pada model pembelajaran Project Based Learning diantaranya adalah motivasi belajar peserta didik untuk belajar akan meningkat, mendorong kemampuan mereka untuk melakukan suatu pekerjaan yang penting, kemampuan dalam memecahkan masalah juga meningkat, membuat peserta didik menjadi aktif serta berhasil memecahkan suatu masalah, memberikan pengalaman kepada peserta didik mengenai pembelajaran dan praktik dalam mengorganisasikan proyek dan dapat membuat alokasi waktu yang tepat serta sumber-sumber lain, salah satunya seperti menyediakan pengalaman belajar dan menunjukkan pengetahuan yang dimiliki, kemudian diimplementasikan dengan dunia nyata sehingga membuat suasana belajar menjadi menyenangkan.

Selain itu juga terdapat beberapa kelemahan pada model pembelajaran Project Based Learming diantaranya adalah menghabiskan banyak waktu untuk menyelesaikan suatu masalah, biaya yang diperlukan cukup banyak, banyak pendidik yang masih nyaman dengan pembelajaran berpusat pada guru, peralatan yang disediakan juga banyak, peserta didik yang memiliki kelemahan dalam mengumpulkan informasi akan mengalami sedikit kesulitan dan kemungkinan peserta didik yang kurang aktif dalam kerja kelompok, tidak dapat memahami materi secara keseluruhan. 
Dengan ini seorang pendidik harus mampu menerapkan model pembelajaran Project Based Learning dengan baik agar dapat meningkatkan motivasi belajar peserta didik. Dari penelitian yang dilakukan oleh (Fitri, 2018) menyimpulkan bahwa model PjBL dan motivasi berprestasi mampu memberikan pengaruh yang lebih besar terhadap kemampuan berpikir tingkat tinggi siswa. (Insyasiska, 2015) menyimpulkan bahwa pada kelas eksperimen memiliki kemampuan kognitif 28,9\% yang dapat dikatakan lebih tinggi daripada kelas kontrol.

Berdasarkan uraian diatas, peneliti ingin mengkaji mengenai pengaruh model pembelajaran Project Based Learning terhadap motivasi belajar siswa. Sekolah yang akan diteliti oleh peneliti adalah SDN Keboananom Gedangan Sidoarjo. Di sekolah tersebut sudah diterapkan pembelajaran menggunakan saintifik dan model pembelajaran sesuai yang dicanangkan pemerintah, namun peneliti belum mengetahui tentang pengaruh model pembelajaran Project Based Learning pada motivasi belajar siswa.

\section{METODE}

Jenis penelitian yang digunakan dalam penelitian ini adalah kuantitatif. Penelitian ini menggunakan desain Quasi Eksperimental. Penelitian ini sulit melakukan random sampling. Penelitian ini hanya memberikan posttest pada kelas eksperimen dan kelas kontrol. Rancangan Nonequivalent Posttest-Ony Control Design dapat ditunjukkan gambar 1

\begin{tabular}{|ccc|}
\hline $\mathrm{R}_{1}$ & $\mathrm{X}$ & $\mathrm{O}_{2}$ \\
\hline $\mathrm{R}_{2}$ & & $\mathrm{O}_{4}$ \\
\hline
\end{tabular}

Gambar 1. Nonequivalent Posttest-Only Control Design

Keterangan:

$\mathrm{R}_{1} \quad$ : Kelas Eksperimen (Menggunakan Model Pembelajaran PjBL)

$\mathrm{X}$ : Perlakuan

$\mathrm{O}_{2} \quad$ : Nilai Posttest Kelas Eksperimen

$\mathrm{R}_{2} \quad$ : Kelas Kontrol (Menggunakan Pendekatan Saintifik)

$\mathrm{O}_{4} \quad$ : Nilai Posttest Kelas Kontrol

Populasi dalam penelitian ini adalah siswa kelas III SDN Keboananom Gedangan Sidoarjo tahun ajaran 2019-2020 yang berjumlah 79 peserta didik dan terdiri dari kelas III A, III B dan III C. Sampel dalam penelitian ini adalah kelas III C sejumlah 27 siswa sebagai kelas eksperimen dan kelas III B sejumlah 26 siswa sebagai kelas kontrol.

Teknik pengumpulan data menggunakan angket motivasi untuk mengumpulkan data tentang pengaruh model pembelajaran PjBL terhadap motivasi belajar siswa kelas III SDN Keboananom Sidoarjo. Teknik analisis data menggunakan statistic deskriptif inferensial. Untuk pengolahan data, penulis menggunakan bantuan program SPSS 16.0. 


\section{HASIL DAN PEMBAHASAN}

Sebelum melakukan penelitian, peneliti meminta masukan dan saran terlebih dahulu ke validator untuk melakukan validasi terkait dengan RPP, lembar observasi peserta didik dan angket motivasi belajar. Untuk memastikan apakah perangkat pembelajaraan telah layak digunakan atau tidak. Jika perangkat sudah layak maka selanjutnya peneliti melakukan uji homogenitas pada kelas yang akan digunakan untuk penelitian. Data yang digunakan untuk uji homogenitas berupa data UH (Ulangan Harian) Tema 1.

Tabel 1. Test of Homogeneity of Variances

\begin{tabular}{rrrrr}
\hline Levene Statistic & df1 & & df2 & \multicolumn{2}{c}{ Sig. } \\
\hline .159 & & 1 & 51 & $\mathbf{. 6 9 2}$ \\
\hline
\end{tabular}

Dari tabel diatas dapat dilihat bahwa nilai signifikansi (Sig.) $>0,05(0,692>0,05)$. Jadi dapat disimpulkan bahwa data tersebut berdistribusi homogen.

Tabel 2. Hasil Angket Motivasi

\begin{tabular}{lcc}
\hline & Kelas Eksperimen & Kelas Kontrol \\
\hline Jumlah Siswa & 27 & 26 \\
\hline Nilai Tertinggi & 98,75 & 71,25 \\
\hline Nilai Terendah & 85 & 56,25 \\
\hline
\end{tabular}

Uji normalitas dalam penelitian ini untuk mengetahui hasil posttest berdistribusi norml atau tidak normal. Hasil uji normalitas menggunakan tabel Shapiro - Wilk karena jumlah kelas eksperimen dan kelas kontrol tidak sama. Uji normalitas dilakukan dengan kriteria data dinyatakan normal jika Sig. $>0,05$ dan dikatakan tidak normal jika Sig. $<0,05$. Berdasarkan hasil analisis berbantuan SPSS, uji normalitas data Sapiro-Wilk nilai Sig. $<(0,05)$ maka distribusi dikatakan tidak normal. Kedua data penelitian dikatakan tidak normal karena mempunyai Sig. $<(0,05)$, yaitu sig. 0,021 untuk kelas eksperimen dan 0,040 untuk kelas kontrol.

Uji homogenitas dilakukan sebagai prasyarat untuk menentukan jenis uji t-test yang akan digunakan. Data dinyatakan homogen jika Sig. $>0,05$ dan dikatakan tidak homogen jika Sig. $<0,05$. Berdasarkan hasil analisis dengan menggunakan SPSS diketahui data posttest memiliki Sig. $>0,05$ yaitu 0,297, sehingga dapat disimpulkan bahwa data posttest homogen. Pada uji normalitas dan uji homogenitas menunjukkan bahwa data yang di dapat berdistribusi tidak normal namun homogen, sehingga meneliti melakukan uji-t menggunakan non parametric. Berikut

Tabel 4. Uji hipotesis t-test

\begin{tabular}{lr}
\hline & \multicolumn{1}{c}{ Nilai } \\
\hline Mann-Whitney U & .000 \\
Wilcoxon W & 351.000 \\
Z & -6.259 \\
Asymp. Sig. (2-tailed) & $\mathbf{. 0 0 0}$ \\
\hline a. Grouping Variable: Kelas &
\end{tabular}


Berdasarkan hasil uji t-test dengan memperhatikan kolom Sig. (2-tailed) dapat diketahui hasil uji t-test dari data posttest memiliki Sig < 0,05 yaitu 0,000. Hal ini menjelaskan bahwa $\mathrm{H}_{\mathrm{O}}$ ditolak. Sehingga hipotesis $\mathrm{H}_{1}$ diterima yang artinya terdapat pengaruh model pembelajaran project based learning terhadap motivasi belajar siswa kelas III SDN Keboananom.

\section{Pembahasan}

Penelitian ini dilaksanakan di SDN Keboan Anom Sidoarjo pada tanggal 31 Oktober 2019. Penulis memilih siswa kelas III yang terdiri dari 3 kelas yakni kelas III-A, III-B, dan III-C. Sebelum penelitian, penulis melakukan uji homogenitas dengan menggunakan nilai UH yang diminta dari wali kelas III-A, IIIB dan III-C pengujian ini dimaksudkan untuk mengetahui apakah kelas yang nantinya akan dijadikan sebagai sampel penelitian berdistribusi homogen atau tidak. Penulis menetapkan kelas III-B dan III-C sebagai kelas yang akan digunakan untuk penelitian. Dari perhitungan tersebut diperoleh nilai Sig. $(0,692>$ 0,05). Data sampel dikatakan homogen jika nilai signifikansi (Sig.)-nya $>0,05$. Jadi dapat disimpulkan bahwa data tersebut berdistribusi homogen. Kemudian penulis melakukan penelitian meng-gunakan model pembelajaran Project Based Learning pada kelas eksperimen yaitu kelas III-C. Dan pembelajaran yang menggunakan pendekatan saintifik untuk kelas III-B sebagai kelas kontrol.

Peneliti memberikan lembar angket motivasi peserta didik dan nilai angket tersebut akan dilakukan perhitungan uji homogenitas, uji normalitas, dan uji Independent Sampel T-Test. Diperoleh dari nilai angket motivasi peserta didik terdapat perbedaan rata-rata antara kelas eksperimen dan kelas kontrol. Pada kelas eksperimen mendapatkan rata-rata sebesar 88,33 dan kelas kontrol yaitu 64,46. Dari kedua kelas tersebut diketahui rata-rata kelas eksperimen lebih tinggi daripada kelas kontrol. Hasil analisis perhitungan uji Independent Sampel T-Test diperoleh Sig. (2-tailed) 0,000. Karena Sig. (2-tailed) 0,000<0,05 dengan demikian $H_{O}$ ditolak, artinya terdapat pengaruh model pembelajaran Project Based Learning terhadap motivasi belajar siswa kelas III SDN Keboan Anom Sidoarjo.

Pada kelas eksperimen terdapat pengaruh model pembelajaran Project Based Learning pada tema 4 subtema 1 pembelajaran 4 kelas III disebabkan oleh karakteristik pembelajaran PjBL itu sendiri dimana peserta didik berperan aktif dalam pembelajaran dan melatih siswa dalam bersosialisasi bekerja dalam suatu kelompok untuk menyelesaikan proyek. Hasil penelitian ini didukung oleh teori konstruktivisme yang menyatakan bahwa pentingnya keterlibatan anak secara aktif dalam proses pengaitan sejumlah gagasan dan pengkonstruksian ilmu pengetahuan melalui lingkungannya. Dengan melakukan proyek berupa poster dimana peserta didik harus menyelesaikan proyek tersebut tanpa bantuan siapapun kecuali dengan semua anggota kelompok. Peserta didik harus bekerjasama untuk mencapai tujuan, dalam pembelajaran ini peserta didik yang berkemampuan lebih tinggi akan memotivasi peserta didik yang kurang untuk ikut aktif dalam penyelesaian proyek. Dengan demikian dapat disimpulkan bahwa terdapat pengaruh model pembelajaran Project Based Learning terhadap motivasi belajar siswa. 


\section{KESIMPULAN}

Berdasarkan pengolahan data dapat disimpulkan bahwa ada pengaruh penggunaan model pembelajaran Project Based Learning (PJBL) terhadap motivasi belajar siswa kelas III SDN Keboananom Sidoarjo. Hal ini dibuktikan dari hasil perhitungan angket motivasi belajar yang diuji menggunakan uji t-test dengan hasil Sig. 0,000. Setelah penulis melakukan penelitian, diharapkan dapat dijadikan referensi atau penambah wawasan tentang Model Project Based Learning dan motivasi belajar. 1) Bagi Pendidik yang menggunakan model pembelajaran Project Based Learning sebaiknya mampu memanfaatkan alokasi waktu dengan baik. Pengelolaan waktu yang baik dapat membantu siswa dalam menyelesaikan tiap tahap pembelajaran sesuai batas waktu yang ditentukan sehingga siswa dituntut lebih aktif dalam menyelesaikan tugas kelompok. 2) Bagi peserta didik diharapkan dapat mengikuti pembelajaran dengan sungguh-sungguh dan lebih memanfaatkan apa yang sudah dipersiapkan pendidik dengan susah payah sehingga dapat mencapai tujuan pembelajaran yang diharapkan. 3) Bagi sekolah guru disarankan lebih banyak menguasai macam-macam model pembelajaran terutama model pembelajaran yang mampu memahamkan siswa dan suasana belajar menjadi senang.

\section{DAFTAR PUSTAKA}

Dangnga, Muhammad Siri., dan Abd. Muis. 2015. Teori Belajar dan Pembelajaran Inovatif. Makassar. SIBUKU Makassar

Dimyati, Mudjiono. 2015. Belajar dan Pembelajaran. Jakarta: PT RINEKA CIPTA

Fanani, Achmad. Bahauddin A., dan Dian K. 2015. Pengembangan Perangkat Pembelajaran Sekolah Dasar. Surabaya: Adi Buana University Press

Fatturohman, Muhammad. 2017. Model-Model Pembelajaran Inovatif. Jogjakarta: Ar-Ruzz Media

Ibnu, Trianto. 2015. Mendesain Model Pembelajaran Inovatif, Progresif dan Kontekstual: Konsep, landasan dan implementasinya pada kurikulum 2013. Jakarta: Prenadamedia Group

Kodir, Abdul. 2018. Manajemen Pembelajaran Saintifik Kurikulum 2013 Pembelajaran Berpusat Pada Siswa. Bandung. CV. Pustaka Setia

Parwati, Ni Nyoman. I Putu P.S., dan Ratih A. 2018. Belajar dan Pembelajaran. Depok: PT RajaGrafindo Perkasa

Setiawan, B., \& Iasha, V. (2020). COVID-19 PANDEMIC: THE INFLUENCE OF FULL-ONLINE LEARNING FOR ELEMENTARY SCHOOL IN RURAL AREAS. JPsd Jurnal Pendidikan Sekolah Dasar), 6(2), 114-123.

Setiawan, B., Rachmadtullah, R., \& Iasha, V. (2020). Problem-Solving Method: The Effectiveness of The Pre-service Elementary Education Teacher Activeness in The Concept of Physics Content. Jurnal Basicedu, 4(4), 1074-1083.

Sudjana, Nana. 2016. Penilaian Hasil Proses Belajar Mengajar. Bandung: PT Remaha Rosdakarya

Sudirman. 2014. Interaksi dan Motivasi Belajar Mengajar. Jakarta: PT RAJAGRAFINDO PERSADA

Sugiyono. 2017. Metode Penelitian Kuantitatif, Kualitatif dan R\&B. Bandung: Alfabeta

Fitri, Hikmatul dkk. 2018. "Pengaruh Model Project Based Learning (PjBL) Terhadap Kemampuan Berpikir Tingkat Tinggi Ditinjau dari Motivasi Berprestasi Siswa Kelas IV Sekolah Dasar". Jurnal Riset dan Konseptual, Vol 3 (2)

Insyasiska, Dewi dkk. 2015. "Pengaruh Project Based Learning Terhadap Motivasi Belajar, Kreativitas, Kemampuan Berpikir Kritis dan Kemampuan Kognitif Siswa pada Pembelajaran Biologi” Jurnal Pendidikan Biologi, Online, Vol 7 (1) 